\title{
The Public-Private Partnership Model in the Management of Early Childhood Policy in Medellin: Case Study*
}

Modelo de asocio público-privado en el manejo de la política para la temprana infancia en Medellín: un estudio de caso

\section{Modelo de parceria público-privada na gestão da política da primeira infância em Medellín: estudo de caso}

Date received: 17 April 2018. Date accepted: 18 August 2018. Date published: 27 May2019

\section{Luz Stella Álvarez Castañoa \\ Universidad de Antioquia, Colombia ORCID: 0000-0002-8049-5685 \\ Juan Diego Goez \\ Universidad de Antioquia, Colombia ORCID: 0000-0002-0851-0924 \\ María Teresa Quintero \\ Universidad de Antioquia, Colombia \\ ORCID: 0000-0003-3715-4348}

How to cite this article: Álvarez Castaño LS, Goez JD, Quintero MT. The public-private partnership model in the management of early childhood policy in Medellin: Case study. Revista Gerencia y Políticas de Salud. 2019;18(36). https://doi.org/10.11144/Javeriana.rgps18-36.pppm

Research article

Corresponding author. E-mail: luz.alvarez@udea.edu.co 


\section{Abstract}

Objective: State outsourcing of the provision of health care policies is part of the neoliberal model. Early childhood policy in Medellin is managed under the public-private partnership modality with private non-profit institutions. The purpose of this study was to establish the philosophical foundations of the policy, the state's control over the policy, pressure from interest groups and the working conditions of workers. Method: It is a qualitative study. Results: It was found that the philosophical foundations of the policy are public because the rights of the child inspire it; the state (city government) leads the policy, defines the guidelines and supervises compliance of objectives. However, the policy is carried out at the expense of the labor rights of professionals, and there is pressure on hiring by interest groups. Conclusion: The outsourcing of public policies to local non-profit organizations has adverse outcomes similar to policy outsourcing carried out through private companies.

Keywords: public-private sector partnerships, primary health care, health personnel management, health services administration, public health administration, child nutrition sciences

\section{Resumen}

Objetivo: La tercerización del estado para la implementación de las políticas de atención médica hace parte del modelo neoliberal. La política de la temprana infancia en Medellín se maneja bajo la modalidad de asociación público-privada con instituciones privadas sin fines lucrativos. El propósito de este estudio fue establecer las bases filosóficas de la política, el control del Estado sobre la política, la presión ejercida por los grupos de interés y las condiciones laborales de los trabajadores. Método: Este es un estudio cualitativo. Resultados: Se encontró que las bases filosóficas de la política son públicas porque los derechos del niño así lo inspiran; el Estado (el gobierno de la ciudad) conduce la política, define las pautas y supervisa el cumplimiento de los objetivos. Sin embargo, la política se lleva a cabo a expensas de los derechos laborales de los profesionales y hay presión sobre la contratación por parte de los grupos de interés. Conclusión: La tercerización de las políticas públicas a organizaciones locales sin fines lucrativos tiene resultados adversos similares a la tercerización de las políticas que llevan a cabo las empresas privadas.

Palabras claves: asociaciones en el sector público-privado, atención médica primaria, manejo del personal de salud, administración de servicios de salud, administración de salud pública, ciencias de la nutrición infantil

\section{Resumo}

Objetivo: A terceirização do estado para a implementação das políticas de atenção médica faz parte do modelo neoliberal. A política da primeira infância em Medellín é gerida sob a modalidade de parceria público-privada com instituições privadas sim fins lucrativos. O propósito do estudo foi estabelecer as bases filosóficas da política, o controle do Estado sobre a política, a pressão exercida pelos grupos de interesse e as condições laborais dos trabalhadores. Método: Foi um estudo qualitativo. Resultados: Verificou-se que as bases filosóficas da política são públicas porque os direitos da criança a inspiram; o Estado (o governo da cidade) conduz a política, define as diretrizes e supervisiona o cumprimento dos objetivos. No entanto, a política é levada a cabo em detrimento dos direitos trabalhistas dos profissionais e há pressão sobre a contratação pelos grupos de interesse. Conclusão: A terceirização de políticas públicas para organizações locais sim fins lucrativos tem resultados adversos semelhantes à terceirização de políticas realizadas por empresas privadas.

Palavras-chave: parcerias no setor público-privado, atenção primária à saúde, gestão do pessoal de saúde, administração de serviços de saúde, administração de saúde pública, ciências da nutrição infantil 


\section{Introduction}

The Colombian state began to finance and implement social policies during the Keynesianism development model period (1930-1980) (1-5). In 1980, Colombia, like most Latin American countries, initiated a series of socioeconomic reforms following a system known as the neoliberal model (6-17). One of the aspects that involved the greatest transformation was the introduction of the private sector in the provision of health services and primary care (18-20), which introduced tools of so-called "new public management" (21).

According to Lundqvist (22), there are different models for the participation of the private sector in the provision of public policies. One of them is privatization, in which a service has a public regulator but is financed and provided by the private sector. Another model is when the state maintains direction, control, financing, and supervision but hires a private firm for the provision of services. The latter is known as outsourcing, which is currently used in countries around the world.

The outsourcing of social policies by the state has been defended based on the assumption that it is more efficient in terms of cost/benefit and improves the quality of services, reducing costs for users and the state (23). In contrast, other authors argue that outsourcing and privatizing by hiring private companies delegitimizes the state due to misuse of resources, corruption, financial scandals and the poor quality of the services provided (24). Besides, the government's savings in terms of public spending have not been demonstrated; on the contrary, the pressure of interest groups increases, and employment decreases (25). In Latin America, criticisms have arisen because of the inevitable consequences of hiring private institutions for the provision of public policies, since their presence requires the generation of profit, the targeting of the beneficiaries of the programs and the behavior of all the actors as that of an interest group, thus losing the public and universal rights of social policies" $(23,26-28)$.

In Medellin, the Early Childhood policy is called the "Programa Buen Comienzo" (Good Start Program). It is carried out through a public-private partnership with two characteristics: the state hires the services of private non-profit institutions for the attention and care of children, and those institutions are exclusively local in nature. That is, in this modality, large capital-intensive international corporations are not involved, as occurs in the majority of state outsourcing around the world. 
The Program "Buen Comienzo" began in 2004 at the initiative of private institutions that proposed its creation to the municipal government. They were inspired by the purpose of stopping the vicious circle of poverty and violence in the city by providing comprehensive care from pregnancy to age 5 to children in the most vulnerable areas of the city.

The Programa Buen Comienzo is affiliated with the Secretary of Education, which depends on the municipal government. Its management model consists of delegating the provision of the service to 58 non-profit private, non-governmental entities called "operators." Childcare is carried out in the Child Development Centers (CDC) (Centros de Desarrollo Infantil, CDI) and kindergartens. The program managers are public officials and oversee direction, supervision, control, and evaluation. The municipal government finances the program in its entirety and directly allocates the resources, which are part of the city's social investment (29).

Different evaluations have emphasized the nutritional aspects of early childhood policy in Medellin. Their findings show improvements in the nutritional and health status of the children in the various age groups covered by the policy as well as enhancementsto the eating habits of the children and their families (30-32). However, the management of the program and the effects of outsourcing under the modality of public-private partnerships have not been evaluated. The objective of this study was to close this knowledge gap with the purpose of establishing whether externalizing social policies with non-profit and local institutions present some of the problems mentioned above, which characterize outsourcing to capital-intensive private firms. The following research questions were posed: Are the philosophical foundations of the policy public or private? Which institutions define the objectives of the policy: public or private institutions? Does the state have the capacity to enforce the objectives of the policy? How do the different actors behave: as collaborators or as actors in conflict pursuing their own interests? What are the working conditions of the workers involved in the policy? Does the state control the evaluation and monitoring processes? Is there pressure from interest groups, and if so, what type of pressure? 


\section{Methodology}

This is a qualitative study in which the documents containing the guidelines of Medellin's Early Childhood policy were analyzed, and in-depth interviews were carried out with the different actors to triangulate information. This study is part of a larger one, aimed at evaluating the Buen Comienzo program with two components: quantitative (to assess the nutritional status of children by using weight, height, and age) and qualitative to evaluate program management. Just aspects related to the qualitative study are presented in this paper.

The Program Buen Comienzo" includes several strategies. The one analyzed in this study is the institutional modality that provides care for children in the most deprived areas of the city for eight hours a day, from Monday to Friday, in four areas of development: nutritional, pedagogical, health and psychosocial. In terms of nutrition, $75 \%$ of their daily caloric requirements are covered by the program (33).

\section{Sampling}

The "Buen Comienzo" Program encompasses 450 care centers and serves 62,000 children in all six zones of the city of Medellin ([Municipality of Medellin], 2017). This study was conducted in 12 care centers chosen at random, located in four areas of Medellin. The 12 centers were chosen to complete the required sample in the quantitative component ( 780 children). The four zones were selected so that the sample had the participation in of the zones of the city in which a greater number of care centers exist.

\section{Participants}

Interviews were conducted with policy managers who work for the municipal government, directors of the non-profit organizations that operate the policy and professionals and assistant staff who attend to children and parents. To collect the information, 52 semi-structured interviews were carried out with the following actors: 12 educational agents (assistant staff serving children); four managers from the care centers working for non-profit organizations; six program managers who work for the municipal government of Medellin (Education Secretariat) in charge of the management of the program; four nutritionists who work for the operators of the program; two nutritionists who work for the auditing institution in charge of the evaluation and 
monitoring of the program and 24 parents. The number of participants was not previously defined, except in the case of Officers in charge of the management of the program (the interviewees correspond to the total). In most cases, the number of participants was due to categories saturation. Only the type of actors was established, but the initial proposal did not include people from the auditing institution. The latter were selected also because more data were needed to saturate categories.

\section{Guide to questions}

To collect the information, the researchers conducted semi-structured individual interviews with the objective of determining the perception of the actors regarding the management of the program. Four question guides were proposed that had a flexible design, which allowed the researchers to modify the topics and questions during data collection. The first guide was implemented with the program managers who work for the municipal government, the second with the education and nutrition professionals, the third with the parents and the four one with auditors. These guidelines were proposed so that the researchers could collect information on each of the aspects to analyze the program. Guides are shown in the Appendix.

The questions that the interviewers asked the managers, auditors, directors of non-profit organizations and professionals about the management of the Buen Comienzo Program were related to the following categories as illustrated in Table 1. These categories are a) Fundamentals of the policy: refers to the principles and main goals that guide policy b) actors that define policy fundamentals: related to private and public institutions that represent the guidelines, goals, child achievements to meet and workers labor conditions. c) The capacity of the state (municipal government) to comply with the objectives. Refers to the state's institutional capacity and structure to meet defined policy objectives d) State control over monitoring and evaluation and possible interest groups. Refers to the ability of the state to maintain the criteria and guidelines defined to face possible interest groups wanting to interfere the policy management e) guarantee of labor rights of professionals refers to wages, benefits, training, tasks, work schedule and each other's balance (Table 1). 
Table 1. Categories and information sources

\begin{tabular}{|c|c|c|}
\hline Category & Documents analyzed & Actors interviewed \\
\hline $\begin{array}{l}\text { Fundamentals of } \\
\text { the policy }\end{array}$ & $\begin{array}{l}\text { - Support program for the development of early } \\
\text { childhood policy: Early childhood policy, } 2006 \\
\text { - Resolution } 12250 \text { of } 2013 \\
\text { - Municipal agreement } 058 \\
\text { - Guidelines and standards for the provision of the } \\
\text { service of comprehensive early childhood care, } 2016\end{array}$ & $\begin{array}{l}\text { - Program managers } \\
\text { - Directors of operators } \\
\text { - Professionals in education } \\
\text { and nutrition } \\
\text { - Assistants } \\
\text { - Parents }\end{array}$ \\
\hline $\begin{array}{l}\text { Actors that define } \\
\text { policy fundamentals }\end{array}$ & & $\begin{array}{l}\text { - Program managers } \\
\text { - Directors of operators } \\
\text { - Professionals in education } \\
\text { and nutrition }\end{array}$ \\
\hline $\begin{array}{l}\text { The capacity of } \\
\text { the state to comply } \\
\text { with the objectives }\end{array}$ & & $\begin{array}{l}\text { - Program managers } \\
\text { - Directors of operators } \\
\text { - Professionals in education } \\
\text { and nutrition } \\
\text { - Auditors }\end{array}$ \\
\hline $\begin{array}{l}\text { State control over } \\
\text { monitoring and } \\
\text { evaluation and } \\
\text { possible interest } \\
\text { groups }\end{array}$ & $\begin{array}{l}\text { - Resolution } 12250 \text { of } 2013 \\
\text { - Municipal agreement } 058 \\
\text { - Guidelines and standards for the provision of the } \\
\text { service of comprehensive early childhood care, } \\
2016\end{array}$ & $\begin{array}{l}\text { - Program managers } \\
\text { - Directors of operators } \\
\text { - Professionals in education } \\
\text { and nutrition } \\
\text { - Auditors }\end{array}$ \\
\hline Labor conditions & $\begin{array}{l}\text { - Resolution } 12250 \text { of } 2013 \\
\text { - Municipal Agreement } 058 \\
\text { - Guidelines and standards for the provision of the } \\
\text { service of comprehensive early childhood care, } \\
2016\end{array}$ & $\begin{array}{l}\text { - Program managers } \\
\text { - Directors of operators } \\
\text { - Professionals in education } \\
\text { and nutrition } \\
\text { - Assistants } \\
\text { - Auditors }\end{array}$ \\
\hline
\end{tabular}

Source: own work

\section{Analysis of the information}

First, the interviews were recorded and transcribed in full. Subsequently, the researchers coded and analyzed the information according to the categories previously defined in the analysis matrix. The coding was open and was used to expand the identification of the properties and dimensions of the categories. The transcripts were analyzed line by line and paragraph by paragraph to discover categories that could be grouped depending on the topics proposed in the information collected. Then, the codes were grouped to establish relationships between them and to elaborate more general categories until reaching content saturation. Next, the structure of the analysis and the interpretation of the results were performed. The coding software used was ATLAS/ti version $7 \AA$. The framework project of this research was approved by the bioethics committee of the Faculty of Medicine of the University of Antioquia through approval act 016 of October 15, 2015. The information was collected from April to November 2016. 
It should be noted that, in the next section, the results are cited according to their respective source of information. The documents that define guidelines and policies are cited using their name in Spanish.

\section{Results}

First, it is important to highlight that the Program's documents allowed us to analyze directions on different aspects including management criteria and labor condition guidelines.

As mentioned earlier, the Programa Buen Comienzo is affiliated with the Secretary of Education, which depends on the municipal government. Its management model consists of delegating the provision of the service to 58 non-profit private, non-governmental entities called "operators." Childcare is carried out in the Child Development Centers (CDC) (Centros de Desarrollo Infantil, CDI) and kindergartens. Due to the program's management model, there are not only different types of actors (public-private) but also actors with different roles, as described in Figure 1.

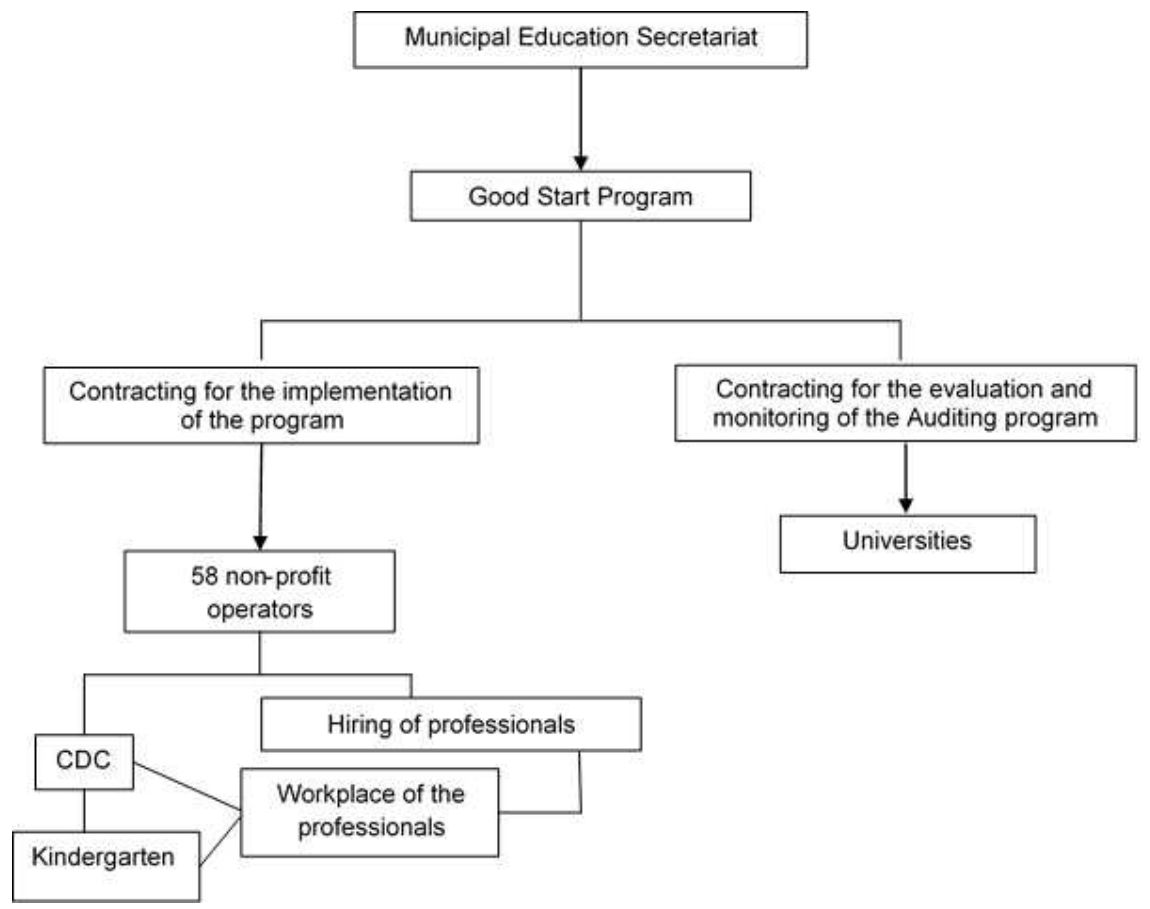

Figure 1. Operational structure of the Good Start Program

8 Source: own work 


\section{The public nature of politics and the role of the state}

One of the research questions in this study was what the philosophical foundations of the policy and what institutions are (public or private) define it. The analysis of the policy's guidelines and the answers of the interviewees show that the guidelines related to all aspects such as feeding the children, work criteria and the monitoring and evaluation systems are elaborated by the state, in this case by the Municipal Education Secretariat. Additionally, the distribution of the program's budget is included annually in the city's development plan, approved by the Secretary of Education and the Municipal Council (33).

The philosophical foundations of the policy are public because it seeks the formation of citizens and the ownership of rights, not just the provision of services. The program is considered as an instrument for the transformation of society and each of the individuals who are part of it (34).

Despite the public nature expressed in its theoretical foundations, in practice, the program has an important restriction because its rights do not apply to all citizens under six years of age. First, it has a targeted selection process aimed at including only the poorest children according to a strict territorial system and social stratification. This excludes the part of the child population that is not as poor.

When the different actors were asked about the philosophical foundations of the program, which institutions define them and to what extent they are shared, it was evident that the state (municipal government) defines the guidelines and controls compliance with objectives, and in all the interviews, it was observed that the actors work toward a common goal. Everyone knows and shares the objectives of the program, highlights their achievements and feels committed to their goals:

We see great progress especially in comparison with the children initial nutritional status. When comparing data from 2012 and 2016, we see that size has slowly increased by $1 \%, 2 \%$, which is supremely important for the city $[. .$.$] and when we see that the data for the entire city have also impro-$ ved, we know that these data include the children of the PBC, and we can say that we also contribute to that indicator moving. (Program manager 1). 
A parent declares regarding the objectives of the program that:

Someone asks of my child: love, what do you go to kindergarten for? And he responds: to be happy... My son comes telling me, that is, tells stories, about what the teacher teaches him: share with your friends, that you must respect your friends, that you have to share. They teach them to be people, to take care of themselves, to be supportive, not only come to play but to learn, also to be formed as little people. (Father of family 10)

We also find that the state (municipal government) can lead the program and summon its different actors, especially the non-profit institutions (operators) to work on achieving the objectives. In part, this is achieved through a strict monitoring and evaluation system (35). While the monitoring processes and results are a constant source of tension between the contracting entity and the contractors (operators), the controls work well and allow the program to meet its objectives.

Our daily work is that which guarantees the rights of children; we are interested in the right to not only food but also educational and training activities with children, with families and with the whole community. (Manager of operator)

\section{The state and the rights of the workforce}

According to the interviewees, the state uses outsourcing to generate precarious working conditions in three relevant aspects: a) instability, b) low salaries and c) lack of balance between training and the skills required for the position as well as responsibilities delegated to the workers vs. the hiring institution.

The workers in the program are professionals and assistant staff in nutrition, pedagogy, and psychology. The assistants are educational agents for early childhood and people who prepare food. All are hired by the operators, which as we mentioned are 58 private, non-governmental, non-profit institutions. The Secretary of Education establishes the salaries of each of the professionals who participate in the BCP every year and does not allow paying lower wages. The protocols establish that the workers involved in the program must be people with excellent training, committed to their work and who work in satisfactory conditions because they have high demands. The policy 
established the importance of having strategies for the promotion of human talent, welfare, and satisfaction of each professional service provider. It is expected that this will benefit the performance of each person because the well-being of the workforce is directly related to the care for children. $(33,34)$.

Workers are hired for short, specific periods, always lasting less than one year. In some cases, as with nutritionists, psychologists and educators, in addition to the above, there is bias in the schedules, which do not even reach part-time, which in Colombia corresponds to four hours a day.

My contract is handled by an operator. It is a fixed-term contract, sometimes three contracts a year. In general, we work until November. During December, January and February, we must wait unemployed without salary to see if they call us again for another contract. (Educational agent 2)

The second conflict expressed by workers is the lack of balance between responsibilities and working conditions, including salary.

The work is excessive because we are assigned 300 children, but not all go to the same institution. There are Centers with 50 children and others with 75 , that is, the nutritionist can easily go to four places, each day to a different place... They should reduce the ratio of nutritionists to children so that we can stay longer in one place. (Nutritionist 4)

As a result of these tensions, there is frustration and overload due to excessive responsibilities:

In other words, I am a subordinate of too many bosses, and I have to respond to many institutions-the operator, the program managers, the auditor-and I have to respond directly to children and their parents. (Educational agent 1)

\section{Pressure on the state by interest groups}

The only interviewees who were willing to talk about this issue were the people involved in the audit. They mentioned that the most critical situation consists of hiring institutions that are constantly poorly rated due to the poor quality of their services. The interviewees attributed both situations to the pressure exerted by interest groups composed of operators and political 
groups in the city, which put pressure on the decision-making officials at the highest level of the municipal administration.

Many times, you can see during the audit that there are operators with negative aspects in their performance, that in the last three years have had serious problems and received reports of serious breaches, that despite receiving a negative evaluation in several components, still continue to be hired. (Auditor 2)

\section{Discussion}

This study found that the state (the city government) leads the Early Childhood policy in Medellin. The rationality of the policy is public because it is inspired by the rights of children and their comprehensive education. The state monitors and controls compliance with the policy objectives and ensures that program operators (private non-profit local institutions) fulfill their commitments to education, nutrition and children's welfare. The study observed that the program actors know and share the objectives and have a common purpose. However, the program produces three adverse outcomes derived from the state outsourcing model. First, the policy has been carried out at a high social cost, that is, at the expense of the labor rights of the professionals involved. It was also found that there is pressure from interest groups - a few cases - demonstrating that some operators manage to be hired even though they have received a poor rating from the institutions that evaluate the quality of the services. Finally, despite the public rationality of the program, aspects such as targeting the most impoverished children prevent the early childhood policy from being a universal right.

In relation to working conditions, what can be observed is that when the state contracts the provision of services with for-profit or non-profit private companies, these conditions are characterized by hiring staff in precarious conditions, as the country's labor regulations generally allow them to hire people for less time and facilitates their dismissal without penalties for the companies. These companies additionally benefit because employees in the private sector tend to be less likely to join unions, leaving employees more vulnerable. Studies conducted in Europe show that private companies that provide public services derive their high profits from being more intensive in their labor resources than other resources and from hiring from a 
vulnerable labor force such as younger people or state employees who have been dismissed and can be hired at lower wages (24).

In the case of the early childhood policy of Medellin, the state establishes rules to ensure contractors do not receive wages lower than the set threshold, but contradictorily, the state is the one that contracts the operators for less than 12 months, causing precarious income due to instability. It is also the state that sets the number of professional technical staff/children ratio. That is, it seems that outsourcing is used so that the state can create working conditions that otherwise could not be admitted.

Some studies on the effects of nonprofit private sector participation in social policies show that, in managing labor relations, public-private partnerships adopt market-inspired procedures even though financial resources are of a nature public. Therefore, civil institutions, although not for profit, are characterized by their flexibility in terms of carrying out the selection, hiring, payment and management of their employees (36).toma como referência a experiência de habilitação de organizações sociais (OS

Another negative outcome found in this research is that some operators are hired although they have been poorly rated in evaluations of the quality of the services provided. This may be due to pressure from coalitions formed between operators and political groups in the city. Some studies have evidenced these pressure practices, especially when private capital-intensive companies are hired, that is, large corporations that, through lobbying and corruption of public officials, manage to access contracts despite their poor performance. The influence of political aspects has been one of the least analyzed topics in the outsourcing processes of public policies since it is assumed that the motivations of this model are strictly economic rationality and financial efficiency. However, in some investigations, the political tendencies of the municipal governments and even the electoral periods have been found to influence the type and intensity of hiring for the provision of public goods by outsourcing (37).

\section{Conclusion}

The problems described are similar to those resulting from outsourcing to large international private corporations. 


\section{References}

1. Hernández M. La salud fragmentada en Colombia 1910-1946. Santa fe de Bogotá: Universidad Nacional de Colombia; 2003.

2. Castro B. Caridad y Beneficencia. El tratamiento de la pobreza en Colombia. 1870-1930. Bogotá: Universidad Externado de Colombia; 2007. 351 p.

3. Arretche MTS. Emergência e desenvolvimento do Welfare State: teorias explicativas. Bol Inf e Bibliográfico em Ciências Sociais. 1995;1(39):3-40.

4. Kuhnle S, Sander A. The Emergence of the Western Welfare State. In: The Oxford handbook of Welfare State. Oxford: Oxford University Press; 2010. p. 61-80.

5. Rodríguez O. Del patronato al aseguramiento en el sistema de protección social. In: Crecimiento equidad y ciudadanía: hacia un nuevo sistema de protección social. Bogotá: Universidad Nacional de Colombia, Facultad de Ciencias Económicas Centro de Investigaciones para el Desarrollo; 2006. p. 197-272.

6. Majone G. Do Estado positivo ao Estado regulador: causas e conseqüências de mudanças no modo de governança. Rev do Serviço Público. 1999;50(1):5-36. Available from: https://revista.enap.gov.br/index.php/RSP/article/view/339

7. Marchesi G. La evolución de la política económica y social en Argentina, Chile y Perú: una visión comparativa. Lima: The University of Texas at Austin Institute of Latin American Studies Center for Latin American Social Policy (CLASPO); 2004. 49 p. Available from: http://www1.lanic.utexas.edu/project/etext/llilas/ claspo/overviews/marchesi.pdf

8. Reuben S, Ayala R. Transformaciones en la política social y en las estructuras sociales centroamericanas. Anu Estud Centroam. 1996;22(2):39-63. http://revistas.ucr.ac.cr/index.php/anuario/article/view/3160

9. Lahera E. Reforma del Estado: un enfoque de políticas públicas. Rev del CLAD Reforma y Democr. 2000 Feb;(16). http://old.clad.org/portal/publicaciones-del-clad/revista-clad-reforma-democracia/articulos/016-febrero-2000/ reforma-del-estado-un-enfoque-de-politicas-publicas

10. Nickson A. Transferencia de políticas y reforma en la gestión del sector público en América Latina: el caso del New Public Management. Rev del CLAD Reforma y Democr. 2002 Oct;(24). Available from: http://old.clad.org/portal/publicaciones-del-clad/revista-clad-reforma-democracia/articulos/024-octubre-2002/ transferencia-de-politicas-y-reforma-en-la-gestion-del-sector-publico-en-america-latina-el-caso-del-new-public-management

11. Barrientos A, Hulme D, Shepherd A. Can social protection tackle chronic poverty? Eur J Dev Res. 2005;17(1):8-23. Available from: https://doi. org/10.1080/09578810500066456

12. Cohen E, Franco R. Gestión social: cómo lograr eficiencia e impacto en las políticas sociales. México: Siglo ventiuno editores; 2005. 316 p. 
13. Fresneda O. Reducción de la pobreza en Colombia: el impacto de las políticas públicas. Programa de las Naciones Unidas para el Desarrollo; 1997. 65 p.

14. Holzmann R. Social protection as social risk management : conceptual underpinnings for the social protection sector strategy paper. Whashington: The World Bank; 1999 Jan. Report No.: 20119. http://documents.worldbank.org/ curated/en/348031468739766346/Social-protection-as-social-risk-managementconceptual-underpinnings-for-the-social-protection-sector-strategy-paper

15. Lampis A. Desafíos conceptuales para la Política de Protección Social frente a la pobreza en Colombia. Rev Estud Soc. 2011;(41):107-121. Available from: https:// dialnet.unirioja.es/descarga/articulo/5751114.pdf

16. Uribe M. Los vaivenes de las políticas sociales en Argentina, Colombia, Chile, México y Uruguay: neo o posneoliberalismo? México: Editorial Porrúa; 2011. 215 p.

17. Uribe M. Enfoques contemporáneos de política social en México. Espiral. 2011;18(52):37-75. Available from: https://www.redalyc.org/articulo. oa? id $=13821307002$

18. Armada F, Muntaner C, Navarro V. Health and social security reforms in Latin America: the convergence of the World Health Organization, the World Bank, and transnational corporations. Int J Heal Serv Planning, Adm Eval. 2001;31(4):72968. Available from: https://doi.org/10.2190/70BE-TJ0Q-P7WJ-2ELU

19. Frenk J. The public/private mix and human resources for health. Health Policy Plan. 1993;8(4):315-326. Available from: https://doi.org/10.5455/msm.2012.24.54-57

20. Mesa-Lago C. History of social security in Latin America. In: International Meeting on the History of Insurance Companies in the World; 2008 May 8-9; Madrid, Spain. Fundación MAPFRE; 2002. p. 1-16. Available from: http://www.mesa-lago.com/ uploads/2/7/3/1/27312653/history_of_social_security_mesa_lago.pdf

21. Laffin M, Mawson J, Ormston C. Public Services in a 'Post-democratic Age': An Alternative Framework to Network Governance. Environ Plan C Gov Policy. 2014;32(4):762-776. Available from: http://dx.doi.org/10.1068/c1261

22. Lundqvist LJ. Privatization: Towards a concept for comparative policy analysis. Journal of Public Policy; 1988;8(1):1-19. Available from: https://doi.org/10.1017/ S0143814X00006826

23. Lieberherr E, Dotterud M. Privatization, outsourcing and public service objectives: An explorative analysis of two network industries. Case Stud Transp Policy. 2017;5(4):681-689. Available from: Available from: http://dx.doi.org/10.1016/j. cstp.2017.07.007

24. Froud J, Johal S, Moran M, Williams K. Outsourcing the State: New Sources of Elite Power. Theory, Cult Soc. 2017;34(5-6):77-101. Available from: https://doi. org/10.1177/0263276417717791 
25. Alonso JM, Clifton J, Díaz-Fuentes D. The impact of government outsourcing on public spending: Evidence from European Union countries. J Policy Model. 2017;39(2):333-348. Available from: http://dx.doi.org/10.1016/j. jpolmod.2017.01.007

26. Bastos PPZ. A economia política do novo-desenvolvimentismo e do social desenvolvimentismo. Econ e Soc. 2012;21(SPE):779-810. Available from: http:// dx.doi.org/10.1590/S0104-06182012000400004.

27. Draibe SM, Riesco M. Estados de bem-estar social e estratégias de desenvolvimento na América Latina. Um novo desenvolvimentismo em gestação? Sociologias. 2011;13(27):220-254. Available from: http://www.scielo.br/pdf/soc/v13n27/ a09v13n27.pdf

28. Lavinas L. How Social Developmentalism Reframed Social Policy in Brazil. New Polit Econ. 2017;22(6):628-644. Available from: https://doi.org/10.1080/13 563467.2017 .1297392

29. Medellín S de educación. Resolución número 12250 de 2013 [Internet]. Colombia; 2013 p. 21. Available from: https://www.medellin.gov.co/normograma/docs/ pdf/r_sedumed_12250_2013.pdf

30. Cardona-Sosa L, Medina C. Efectos del Programa Buen Comienzo en los indicadores de los niños y niñas al nacer y en su continuidad escolar: Resultados de la Evaluación No-Experimental. Medellín: Banco de la República; 2013. 61 p. Available from: https://studylib.es/doc/6693530/efectos-del-programa-buencomienzo-en-los-indicadores-de-...

31. Ledesma-Ríos NI, Sepúlveda-Herrera DM, Cárdenas-Sánchez DL, ManjarrésCorrea LM. Ingesta de energía y nutrientes en niños de 2-4 años que asisten al programa "Buen Comienzo", Medellín (Colombia). Nutr Hosp. 2016;33(5):10521061. Available from: https://doi.org/10.20960/nh.566

32. Álvarez-Castaño LS, Góez-Rueda, JD, Quintero-Morales, MT. Evaluación del componente nutricional del Programa Buen Comienzo de Medellín. Perspectivas en Nutrición Humana. 2017:18(1): 61-74. Available from: https://doi.org/10.17533/ udea.penh.v18n1a06

33. Rios F. Acuerdo municipal 058 de 2011. Plantilla para Proyecto de Acuerdo para Sanción. 2011. Completar datos de: Ciudad, País, y un link puesto que esto debe estar público en internet.

34. Alcaldía de Medellín, Secretaría de Educación. Lineamientos y estándares para la prestación del servicio de atención integral a la primera infancia. 2016. Medellín.

35. Decreto página 15: Colombia, Ministerios de Agricultura y Desarrollo rural. Decreto 1277 [Internet]. Bogotá; 2013. Available from: http://wsp.presidencia. gov.co/Normativa/Decretos/2013/Documents/JUNIO/21/DECRETO 1277 DEL 21 DE JUNIO DE 2013.pdf 
36. Barbosa N. Regulação do trabalho no contexto das novas relações público versus privado na saúde. Saúde Coletiva. 2010;15(5):2497-2506. Available from: http:// dx.doi.org/10.1590/S1413-81232010000500024.

37. Elinder M, Jordahl H. Political preferences and public sector outsourcing. Eur J Polit Econ. 2013;30(Supplement C):43-57. Available from: https://doi. org/10.1016/j.ejpoleco.2013.01.003

\section{Declaration of conflicting interests}

The authors declare no potential conflict of interest regarding the research, authorship, and/or publication of this article.

\section{Funding}

This study was funded by the 2014-2015 CODI sustainability strategy of the University of Antioquia.

\section{Appendix}

\section{Guide questions}

1. Program managers

Identification: What are your tasks in the Program?

How long have you been in office?

- What are the objectives of the program?

- How are the guidelines of the Program decided?

- What is the program's monitoring, evaluation and auditing system?

- What evaluations on the program have been made?

- How do you decide changes to make in the program operation?

- How is the Program's budget allocated?

- How is the Program staff hiring process?

- How is the Educational agent/children ratio decided?

- Are you satisfied with your working conditions, including wages?

2. Educational agents

Identification: What are your tasks in the Program? 
How long have you been in this position?

- What are the objectives of the program?

- Do you agree with the Program's goals?

- During the period that you have been in office: Do you know changes in the Program guidelines? What kind of changes? What do you think on them?

- what do you think on the hiring process?

- How many children are you in charge of?

- What is the program's monitoring, evaluation and auditing system?

- Are you satisfied with your working conditions, including wages?

3. Parents

- How long has your child been in the Program?

- What do you think that the objectives of the program are?

- Do you know what activities the children perform in the Children's Center?

- What values are taught to children in the Program?

- Have you or any member of your family been called to participate in the program's activities? For what? Have you attended?

4. Auditors

Identification: What are your tasks in the Program?

How long have you been in office?

- Do you know and share the program objectives?

- What is the program's monitoring, evaluation and auditing system?

- What evaluations of the program have been made?

- How do you decide changes to make in the program operation?

- Is the evaluation used to decide the program outsourcing process?

- How is the hiring process?

- How do you evaluate the program labor conditions? 